Forster, E. M. (1910) Howards End. Harmondsworth: Penguin Books ( 1977 edition).

HARE, E. H. (1983) Was insanity on the increase? British Journal of Psychiatry, 142, 439-55.

LiDz. T. (1973) Family studies and a theory of schizophrenia. In Annual Review of the Schizophrenic Syndrome, Vol 3 (ed. R. Cancro). New York: Brunner/Mazel.

Parnas, J., Schulsinger, F., Teasdale, T. W., Schulsinger, H., Feldman, P. M. \& Mednick, S. A. (1982) Perinatal complications and clinical outcome within the schizophrenia spectrum. British Journal of Psychiatry, 140, 416-20.

Rieder, R. O., ManN, L. S., Weingerger, D. R., van Kammen, D. P. \& Post, R. M. (1983) Computerised tomographic scans in patients with schizophrenia. schizo-affective and bipolar affective disorder. Archives of General Psychiatry, 40, 735-9.

WALLIS, G. G. (1965) An epidemiological and follow-up study of schizophrenia in the Royal Navy. MD Thesis, University of London.

\section{MENTAL ILLNESS, EPILEPSY AND HYPOTHYROIDISM IN XXYY SYNDROME}

DEAR SIR,

I am reporting a case of XXYY syndrome, associated with psychotic episodes, epilepsy and hypothyroidism. The patient is a nineteen year old male with the clinical features of XXYY syndrome, confirmed by cytological investigations.

His height is $194 \mathrm{cms}$. His intellectual assessment showed him to be in the low average range of intelligence (IQ varied from 72 to 88 ). There is no familial or prenatal history available, as the patient was adopted at five years of age. There is a history of epilepsy following a febrile illness at six months and a further convulsion at the age of five years following a smallpox vaccination. An EEG confirmed that he suffered from temporal lobe epilepsy with both grand mal and partial attacks.

The patient first came to the attention of psychiatric services when he was ten years old. The reasons for referral were slow learning, marked fantasy flights, behaviour difficulties and a very high degree of anxiety and tension within the family. At the age of fourteen years his problems increased: his behaviour became worse, he developed transvestite fantasies and started stealing ladies underwear. After being admitted to a special school, he started to steal money from other residents, became argumentative, at times depressed, and attempted suicide by trying to cut his wrists.

Since his admission to a mental hospital in 1983 his mental state is gradually improving and he is now placed in a small hostel and attending the hospital occupational therapy department. His epilepsy is fairly well controlled. Psychotic disorder and EEG abnor- malities in the XXYY Syndrome have been described by Jancar (1968).

In addition to abnormal mental functioning and epilepsy, it was noted that the patient tended to be sleepy. His pulse rate was 56 per minute, total thyroxine was $64 \mathrm{~mol} / \mathrm{l}$ and his free thyroxine index was 61 units. Treatment for hypothyroidism started with $L$ thyroxine $0.1 \mathrm{mg}$ daily to which the patient responded well.

\section{Ballamona Hospital, \\ Braddan,}

Martin Vanyan

Isle of Man

\section{References}

JANCAR, J. (1968) XXYY with manic depression. Lancet, ii, 970.

\section{PSYCHOSIS AND ANTIDIURETIC HORMONE}

\section{DEAR SIR,}

We were interested in the letter from Emsley and Gledhill (Journal, March 1984, 144, 331-2) and would like to make the following observations.

The possibility of a common neurological/hypothalamic disturbance was considered in our paper but discounted in the absence of abnormal drinking behaviour and fluctuation in body weight, with an appropriate ACTH response to hypocortisolaemia. However our patient's prolactin level was normal (370 $\mathrm{mU} / \mathrm{L}$ n.r. $<450 \mathrm{~m} \mathrm{U} / \mathrm{L}$ ). This is of interest since in acutely adrenalectomised rats serum prolactin levels are elevated (Ben-David et al, 1971) suggesting lack of dopaminergic inhibition. Pituitary dopamine and dopamine metabolite concentrations have, however, been found to be normal in adrenalectomised rats (Leung et al, 1980). The mechanism of hyperprolactinaemia is unexplained, but our patient's prolactin level possibly implies an isolated disturbance of hypothalamic function.

While we agree that both present and past phenothiazine therapy may be misleading in interpreting antidiuretic hormone (ADH) levels it seems unnecessary to postulate a drug effect in the presence of such profound hypoadrenalism, with salt and water loss. Moreover Raskind et al (1978) whom they cite as evidence for serum ADH elevation in psychosis only discontinued drugs for 4 weeks before the $A D H$ levels were taken.

We would suggest that further studies to investigate the relationship between $\mathrm{ADH}$ per se and psychosis will need to demonstrate that (a) variations in $A D H$ levels correspond to the course of the psychosis, (b) $\mathrm{CSF} A \mathrm{ADH}$ levels as well as serum $\mathrm{ADH}$ levels are raised during psychosis, (c) these disturbances are 
independent of the state of hydration, electrolyte imbalance and drugs.

Institute of Psychiatry,

S. A. Stansfield

De Crespigny Park,

Denmark Hill,

London SE5 8AF

King's College Hospital, Denmark Hill,

SES 9RS

E. G. LeVER

\section{References}

Ben-Davio, M. DAnon, A., BenYeniste, R, Wellek, C. P. \& Suluman, F, G. (1971) Results of radioimnunoassays of rat pituitary and serum prolactin after adrenalectomy and perphenazine treatment in rats. Journal of Endocrinology, 50,599-606.

Lfung, F. C. Chen, H. T., Verkaix, S. J., Steger, R. W. Pezuso, J. J., Campbel., G. A. \& Metes. J. (1980) Mechanism(s) by which adrenalectomy and corticosterone influence projactin release in the rat. Journal of Endocrinology. 87, 13!-40.

Raskind. M. A. Wetrzman, R. E.. Orenstein, H., Fisher. D. A. \& Courtwey. N. (1978) Is antidiuretic hormone elevated in psychosis? A pilol study. Biological Psychiarry, 13, 385-901.

\section{DEAR SIR,}

\section{SUICIDAL BEHAVIOUR IN CHILDREN}

Dr McClure's recent reports on suicide trends (Journal, February 1984, 144, 119-26, 134-8) give cause for concern, with figures showing a marked increase in deaths due to 'suicide by poisoning', 'accidental poisoning', and 'undetermined poisoning' in the younger age groups. This concern is sustained after noting the continued increase in the 1982 figures from the Office of Population Censuses and Surveys.

Whilst it is generally accepted that suicide is rare in the under 14 age group, this should be distinguished from the more common problem of suicidal behaviour. Kosky (1983) has recently reported this behaviour in children as young as 5 ! The difficulty of thinking of young children having the capacity for suicidal behaviour may account in part for the misclassifications and under-estimations of suicide rates.

As I have previously noted (Halasz, 1984), it is essential for clinicians, confronted with a child having ingested a noxious substance, to include in the differential diagnosis (a) Accidental poisoning, (b) suicidal behaviour and (c) a malignant form of child abuse-intentional poisoning. However unpleasant and anxiety provoking, it is the clinician's responsibility to consider all possible causes of poisoning, whether accidental or intentional. This should lead to rational intervention and generate statistics accurately reflecting the incidence of the separate conditions of accidental, suicidal or intentional poisoning in the young. Only through this process will effective preventative measures be formulated.

The Maudsley Hospital,

George Halasz

Denmark Hill,

London SES 8AZ

\section{Rotorencos}

HaLASZ, G. (1984) Accidental poisoning in childhood. British Medical Journal. 288, 408.

KoskY, R. (1983) Childhood suicidal behaviour. Journal of Child Psychology and Psychiatry, 24, 457-68.

Office of Population Censuses and Suryeys (1982) Mortality Statistics: Cause, London: Her Majesty's Stationery Office.

\section{COIN RECOGNITHON IN THE ELDERLY}

DeAR SIR,

The recognition of decimal (post 1971) and predecimal coins may be used as a measure of memory in the elderly. It is precise and applicable to people of varying backgrounds. Three groups of in-patients. aged over 65 were tested with six decimal and seven pre-decimal coins.

Sixty-three schizophrenics, average age 77 and first admitted 50 years earlier, recognised only $25 \%$ of decimal coins but $64 \%$ of pre-decimal. Those visiting the hospital shop performed marginally better. Seventy-one demented patients, average age 81 , hospitalised 18 months, knew $10 \%$ of new coins and $34 \%$ of the old. Again those who shopped were better but medication or duration of stay made no difference. Of 29 depressives, average age 73 , less than one year in hospital, 27 recognised all coins faultessly and 2 made a minor mistake.

The test was quickly performed with only a pocketful of coins. The long-stay patients were less incapacitated when tested with old, for them familiar, coins. They may show other forms of behaviour which would be less abnormal if viewed from the patient's rather than the younger therapist's position. Staff, impressed by revealed abilities, developed conversations based on other recalled events. It is difficult to measure recall procedures used with the elderly; the recognition of coins is one way.

Clatterbridge Hospital,

M. T. MALCOLM

Bebington,

Wirral.

Merseyside L63 4JY 